\title{
Monoclonal Antibody Mono-dgA-RFB4
}

National Cancer Institute

\section{Source}

National Cancer Institute. Monoclonal Antibody Mono-dgA-RFB4. NCI Thesaurus. Code C2611.

An immunotoxin of monoclonal antibody (MoAb) RFB4 covalently linked to a single deglycosylated ricin toxin A-chain (dgA), originated from castor beans. MoAb RFB4 recognizes CD22 antigen, a B-cell adhesion protein expressed on malignant cells in about 70 percent of non-Hodgkin lymphoma and chronic lymphocytic leukemia. Ricin toxin Achain, a potent protein synthesis inhibitor, was deglycosylated and was used in this immunoconjug ate to avoid hepatic entrapment. This agent limits specific cytotoxicity of ricin toxin to CD22-positive malignant cells. 